\section{Assessment of Partial Peat Substitutes for the Production of Camellia japonica}

\author{
Federica Larcher ${ }^{1}$ and Valentina Scariot \\ Department of Agronomy, Forestry and Land Management, University of \\ Turin, Via Leonardo da Vinci, 44-10095 Grugliasco (TO), Turin, Italy
}

Additional index words. Camellia, substrates, renewable materials, byproducts, growth index

Abstract. Peat is widely used for container plant production. As a result of its high costs, decreasing availability, and environmental concerns, alternative substrates for potting ornamentals are needed. In the present study, five peat substitute materials (local green compost, pumice, coconut fibers, coconut "peat," and pine bark) were evaluated to assess their suitability for containerized acidophilus ornamental plant production. Camellia was chosen as the indicator crop and, to verify the influence of genotype on cultivation response, three different cultivars were used. The main physical, chemical, and biological properties of the substrates were determined before and at the end of the culture and were in general within the acceptable ranges. Except for the negative effect of green compost, during the cultivation period ( 2 years), the alternative materials did not affect or slightly improved the plant development and the ornamental characteristics compared with the standard substrate. Among the materials tested, considering both technical and economical factors, coconut fibers were a good partial peat substitute for potted camellia production.

Peat is widely used in the ornamental nursery industry as a major constituent of growing media for container plant production. In recent years, environmental concerns about peat extraction in wetland ecosystems have risen. Conservation of existing biodiversity in agricultural landscapes and the adoption of biodiversity-based practices have been proposed as ways of improving the sustainability of agricultural production through greater reliance on ecological goods and services with less damaging effects on environmental quality and biodiversity (Jackson et al., 2007). Furthermore, in southern Europe, peat is imported and its cost has become more expensive and its properties more variable (Ribeiro et al., 2007). Thus, the availability of environmentally friendly substrates with good quality, low cost, and obtainable in great quantity is attracting more attention.

Recently, several formulations of alternative materials for potting ornamental plants are being developed, in particular for herbaceous and annual species. The use of alternative growing media requires knowledge of their physical and chemical properties re-

\footnotetext{
Received for publication 25 June 2008. Accepted for publication 3 Dec. 2008.

This study was financially supported by Regione Piemonte, grant n. 345/12-29.11.2004.

We thank Elena Accati and Giovanni Serra for their precious and far-seeing advice; Consorzio Fiori Tipici del Lago Maggiore and Tecnoverde (VB) for technical support; Renzo Bizioli, Gianni Morandi, Elena Costa, and Paola Gullino for their assistance in the experimental work; MAC of Vertemate con Minoprio and Ce.R.S.A.A. of Savona for their assistance in physicochemical and biological analyses; and Agrimedia and Cooperativa Sociale Risorse (VB) for providing substrates.

${ }^{1}$ To whom reprint requests should be addressed; e-mail federica.larcher@unito.it.
}

sponsible for providing adequate support and a reservoir for air, water, and nutrients. The influence of the alternative substrates on plant growth and ornamental traits needs to be evaluated during the entire cultivation period. Studies have indicated that various organic substitutes can be used effectively as support media. Among these, coco fibers are increasingly used as substrate because they have many characteristics in common with peat (Lennartsson, 1997). This material is now being successfully used as a peat substitute for several container-grown ornamental plants such as Dieffenbachia (Stamps and Evans, 1997) and Grevillea (Offord et al., 1998). The feasibility of using pine bark mixtures in substrate formulation was shown in Pinus and Cupressus by Guerrero et al. (2002) and Hernández-Apaolaza et al. (2005). The effect of adding composted waste to a peat growing media is both economically and environmentally attractive (Erhart et al., 2005; Hargreaves et al., 2008). Studies on the use of green waste as a partial substitute for peat in growing media have been carried out, for example, in Gerbera (Pinamonti et al., 1997), Impatiens and Antirrhinum (Klock, 1997), Calendula and Calceolaria (Prasad and Maher, 2001), Cyclamen and Begonia (van der Gaag et al., 2007), and Philodendron (Grigatti et al., 2007). In Gerbera, coco peat was also successfully used (Barreto and Jagtap, 2006). Several studies concern the use of inorganic materials as peat substitutes for ornamental pot plant production. Expanded perlite appears to be the most used (Guérin et al., 2001; Marfà et al., 2002). Other inorganic substrates may also act as peat substitutes, like expanded clay, volcanic lapilli, and pumice (Fascella et al., 2003). the effect of peat alternatives in the pro-
However, little literature is available on duction of containerized woody ornamentals (Scagel, 2003), especially those which in nature grow in acidic soils (such as camellia, rhododendron, and azalea).

This study aimed to evaluate the suitability of four organic and one inorganic materials as partial peat substitutes for sustainable production of Camellia japonica L. To verify the influence of genotype on cultivation response, three cultivars were used.

\section{Materials and Methods}

Experimental design. The study was carried out in a commercial nursery devoted to producing acidophilus ornamental plants located in the Piedmont district (northern Italy), which tested the alternative substrates compared with the standard (S) currently used in production.

The substrates were composed of five peat substitutes (local green compost, pumice, coconut husk processed into fibers, composted coconut "peat," and pine bark) mixed with the standard substrate (commercial Sphagnum peat and agriperlite) at $30 \%$ by volume. Coconut fibers are byproducts of coir factory obtained by separating the coconut husk from the shell and processing the husk into fibers. Coconut peat, also known as coco pith or coco dust, is a byproduct of extracting fibers from the husk of coconuts, heat-treated, and partially decomposed with similar cation exchange capacity as sphagnum peat. Commercial Sphagnum peat (Alce and Silver Torf) was supplied by Agrochimica (Bolzano, Italy), whereas coconut fibers, coconut peat, and pine bark were supplied by Tref Ego Substrate BV (Moerdijk, The Netherlands). Green compost (waste mainly originating from gardens and parks) and pumice were obtained by local producers (Cooperativa Sociale Risorse, San Bernardino Verbano, Italy). Both substrate denomination (acronym) and composition as well as relative costs based on mean European prices are presented in Table 1.

A completely randomized greenhouse experiment with three replications with eight rooted cuttings was carried out from Feb. 2005 to May 2007. Six substrates were tested for three camellia cultivars selected according to their commercial and ornamental value: 'Charles Cobb's', 'Nuccio's Pearl', and 'Dr. Burnside'.

Physical, chemical, and biological characterization. Substrate's characteristics were assessed by measuring appropriate indicators and comparing them with desired values before and at the end of the experiment (Arshad and Martin, 2002).

The physicochemical parameters were determined according to the European (EN) standards (EN13037, EN13038, EN13041, and EN13652) as described by de Kreij and Wever (2005). Bulk density (BD), particle density (PD), porosity (PR), free air space (AS), and water holding capacity (WC) were evaluated using the EN13041 method. pH, electrical conductivity (EC), and soluble chemical elements were determined in aqueous 
Table 1. Composition of the substrates tested and their relative cost referred to the standard.

\begin{tabular}{llr}
\hline Substrate & \multicolumn{1}{c}{ Composition $(\% \mathrm{v} / \mathrm{v})$} & Relative cost \\
\hline S & $89 \%$ Sphagnum peat $+11 \%$ agriperlite (standard substrate) & 100 \\
SGC & $70 \%$ standard substrate $+30 \%$ green compost & 81 \\
SP & $70 \%$ standard substrate $+30 \%$ pumice & 111 \\
SCF & $70 \%$ standard substrate $+30 \%$ coconut fibers & 102 \\
SCP & $70 \%$ standard substrate $+30 \%$ coconut peat & 102 \\
SPB & $70 \%$ standard substrate $+30 \%$ pine bark & 133 \\
\hline
\end{tabular}

extract (substrate/water ratio: $1 / 5 \mathrm{v} / \mathrm{v}$ ) using the EN13037, EN13038, and EN13652 methods with minor modifications, respectively. $\mathrm{N}-\mathrm{NO}_{3}$ and $\mathrm{P}_{2} \mathrm{O}_{5}$ were evaluated by ultraviolet-VIS spectrophotometry. $\mathrm{K}^{+}, \mathrm{Ca}^{++}$, and $\mathrm{Mg}^{+}$were measured by atomic emission spectrophotometry. Ammonia nitrogen $(\mathrm{N}$ $\mathrm{NH}_{4}$ ) was measured by Kjeldahl digestion. All analyses were done in duplicate (GarciaGomez et al., 2002).

Seed germination assay was carried out following Italian standards for compost analysis (UNI 10780). Seed germination and radicle length tests were carried out on water extracts obtained by centrifuging ( $2340 \mathrm{~g}$ for $30 \mathrm{~min}$ ) and filtering, through $0.45-\mu \mathrm{m} \mathrm{mem}-$ brane filters, the fresh samples at a solid:distilled water of 1:10 (w/v dry weight basis). The water extracts were then diluted with distilled water $(50 \%$ and $75 \%)$. A total of 1.0 $\mathrm{mL}$ of each pure and diluted extract was pipetted into a sterilized plastic petri dish lined with Whatman No. 1 filter paper. Ten cress seeds (Lepidium sativum L.) were scattered on the filter paper and incubated at 27 ${ }^{\circ} \mathrm{C}$ in the dark for $72 \mathrm{~h}$. Five replicates were analyzed for each sample. Treatments were evaluated by counting the number of germinated seeds and measuring the length of the radicles. The responses were calculated after 24,48 , and $72 \mathrm{~h}$ by a germination index (GI) according to the following formula (Zucconi et al., 1981):

$$
\begin{aligned}
& \text { GI }(\% \text { of the control }) \\
& \quad=(\mathrm{Gs} * \mathrm{RLs}) /(\mathrm{Gc} * \mathrm{RLc}) * 100
\end{aligned}
$$

Gs $=$ average number of germinated seeds on water extract of the substrate pure or diluted at $50 \%$ or $75 \%$ (sample);

RLs $=$ radicle length of germinated seeds on water extract of the substrate pure or diluted at $50 \%$ or $75 \%$ (sample);

$\mathrm{Gc}=$ average number of germinated seeds on distilled water (control); and

$\mathrm{RLc}=$ radicle length of germinated seeds on distilled water (control).

Cultivation of camellias and growth and flowering control. Cultivation of C. japonica cultivars lasted 2 years (2005 to 2007). Before planting, the substrates were added with: $2.25 \mathrm{~kg} \cdot \mathrm{m}^{-3} \mathrm{CaCO}_{3}, 1.12 \mathrm{~kg} \cdot \mathrm{m}^{-3}$ Osmocote Exact $^{\circledR}$ (15-9-9 + micronutrients, 8-9 months; Scotts, Marysville, $\mathrm{OH}), 0.5 \mathrm{~kg} \cdot \mathrm{m}^{-3}$ Cornunghia, a nitrogenous organic fertilizer, a byproduct of a meat factory (Manna Italia, Andriano, Italy), and $0.5 \mathrm{~kg} \cdot \mathrm{m}^{-3}$ Scorie Thomas, a phosphatic inorganic fertilizer, a byproduct of the iron and steel industry (Timac Italia, Ripalta Arpina, Italy). Then, plants were watered and fertigated with $20 \mathrm{~N}$ $20 \mathrm{P}_{2} \mathrm{O}_{5}-20 \mathrm{~K}_{2} \mathrm{O}$ Peter Professional hydrosol- uble fertilizer (Scotts) at 0.8 to $0.9 \mathrm{~g} \cdot \mathrm{L}^{-1}$ about once every 2 weeks from March to October, according to weather conditions. In February, camellia rooted cuttings were planted in plastic pots ( $9 \mathrm{~cm}$ in diameter), two in each. After 9 months in cultivation, plants were transplanted in $15-\mathrm{cm}$ diameter pots and pruned. In June 2006, plants were induced to branch using paclobutrazol (Cultar ${ }^{\circledR}$; Syngenta Agro S.A., Madrid, Spain) and daminozide (Alar ${ }^{\mathbb{\circledR}}$; Uniroyal Chemicals Ltd, Slough, U.K.) sprayed twice $(100+100 \mathrm{ppm}$ and $80+$ $100 \mathrm{ppm}$, respectively) at an interval of $10 \mathrm{~d}$. The cultivation ended in May 2007, when the flowered pots were suitable for the market.

Plant growth and ornamental characteristics were evaluated during the different cultivation phases (potting, before repotting, before and after branching, and at the end of the experiment).

Plant height and diameters ( $\mathrm{w}_{1}$ across the widest side of the plant and $\mathrm{w}_{2}$ across the side obtained turning it $90^{\circ}$ ) and number of branches produced were recorded per each pot. Plant height and diameters were used to calculate the growth index $=\pi\left\{\left[\left(\mathrm{w}_{1}+\mathrm{w}_{2}\right) / 2\right] /\right.$ $2\}^{2} \mathrm{~h}$, according to Hidalgo and Harkess (2002).

To indirectly measure leaf chlorophyll content and plant health (Smith et al., 2004), the Chlorophyll Meter SPAD-502 Konica Minolta (Nieuwegein, The Netherlands) was used. Measurements were performed on four leaves randomly chosen within each replicate, with each measure being the mean value of two measures on the same leaf.

When the plants reached commercial size, the aerial part of each plant was oven-dried at $90{ }^{\circ} \mathrm{C}$ until a constant weight was obtained and dry weight was determined. For evaluating root quality, the density of the visible roots at the substrate surfaces (side and bottom) was visually estimated by three referees using four classes of roots covering: $1=0 \%$ to $25 \%, 2=26 \%$ to $50 \%, 3=51 \%$ to $75 \%$, and $4=76 \%$ to $100 \%$.

Referring to the aesthetic value, the width of four flowers randomly chosen within each replicate was measured.

Statistical analyses. To analyze camellia growth, health and ornamental data, and also the interaction between cultivar and substrate, results were subjected to an univariate analysis of variance. Germination index data were subjected to a one-way analysis of variance. All data were tested using Student-NewmanKeuls using the SPSS statistical package (Version 13.0; SPSS Inc., Chicago, IL).

\section{Results}

Characteristics of growing media. Many factors affect the level of nutrients available for plant uptake from container media during cultivation, including temperature, moisture, losses to leaching and volatilization, microbial activity, and the physical, biological, and chemical attributes of the media. This study focused on media characteristics and plant response.

Physical properties that must be considered in preparing potting substrates include $\mathrm{BD}, \mathrm{PD}$, total porosity, AS, and WC (Moldes et al., 2007). Bulk and particle densities presented highest values for substrates containing green compost and pumice, respectively (Table 2). Other important properties for plant growth are $\mathrm{pH}, \mathrm{EC}$, and nutrients (Table 3). Camellias are calcifuge plants that grow naturally in acid soils. The $\mathrm{pH}$ of standard substrate was 3.95. In the other media, the $\mathrm{pH}$ was higher, ranging from to 4.12 (SCF) to 5.84 (SGC). During the course of the experiment, $\mathrm{pH}$ increased in all substrates but remained within the range considered suitable for camellia plant container production; likewise for previous studies (Hernández-Apaolaza et al., 2005; Meerow, 1994, 1995). EC was also well within the acceptable range (Abad et al., 2001) both before and at the end of cultivation. Coconut and bark typically contribute few soluble salts to growing media. Pumice does not contain water-soluble salts and nutrients. Differently, green compost has a high salt content, especially potassium. So in the tested media, the major contribution to the EC was related to the peat, except in SGC. At the end of cultivation, increase in $\mathrm{EC}$ and in the amount of available nutrients was detectable in all substrates equally fertigated. Table 4 shows results of the germination bioassay after 48 and $72 \mathrm{~h}$ of incubation. GI, which combines the measurement of seed germination and radicle elongation of cress seed relative to the control, is the most sensitive parameter used to evaluate the toxicity of composts (Gutiérrez-Miceli et al., 2007; Zucconi et al., 1981). It was also used to determine the biological characteristics of other substrates (lake sediments, Beltrami et al., 1999; cattle dung, Hoekstra et al., 2002) because it is an easy and inexpensive screening test. Peat usually promotes germination in a few hours, but, being poor in nutritive elements, can have negative effects on plantlet development after 2 to $3 \mathrm{~d}$. Therefore, the GI estimated after $72 \mathrm{~h}$ of incubation can often give a more comprehensive representation of the substrate's properties. All substrates evaluated showed high GI (greater than $50 \%$ ). After $2 \mathrm{~d}$, GI mean values of the substrates containing peat or coconut peat, $\mathrm{S}$ (135) and SCP (129), were significantly higher than SGC (94), SP (95), and SPB (82). After $3 \mathrm{~d}$, more significant differences in GI responses among substrates were detected: SGC (86), SP (81), and SPB (70) continued to show comparable results, lower than SCP (117) and S (153). In particular, the latter statistically outperformed SCP.

Camellia plant development. Plant growth responses to different media types are usually based on biomass measurement. In ornamentals, this parameter alone may not adequately 
Table 2. Physical properties of the six substrates tested in the research before and at the end of cultivation based on the method of analysis EN13041 (de Kreij and Wever, 2005).

\begin{tabular}{|c|c|c|c|c|c|}
\hline Substrates & $\begin{array}{l}\text { Bulk density } \\
\quad\left(\mathrm{kg} \cdot \mathrm{m}^{-3}\right)\end{array}$ & $\begin{array}{c}\text { Particle density } \\
\left(\mathrm{kg} \cdot \mathrm{m}^{-3}\right)\end{array}$ & $\begin{array}{c}\text { Total porosity } \\
(\% \mathrm{v} / \mathrm{v})\end{array}$ & $\begin{array}{c}\text { Free air space } \\
(\% \mathrm{v} / \mathrm{v})\end{array}$ & $\begin{array}{l}\text { Water holding } \\
\text { capacity }(\% \mathrm{v} / \mathrm{v})\end{array}$ \\
\hline \multicolumn{6}{|c|}{ Before cultivation } \\
\hline $\mathrm{S}$ & 80 & 1,710 & 95.2 & 26.0 & 69.3 \\
\hline SGC & 230 & 2,010 & 88.7 & 22.2 & 66.4 \\
\hline SP & 180 & 2,300 & 92.3 & 33.3 & 59.0 \\
\hline $\mathrm{SCF}$ & 80 & 1,570 & 94.7 & 35.9 & 58.8 \\
\hline SCP & 80 & 1,800 & 95.4 & 25.8 & 69.6 \\
\hline SPB & 120 & 1,690 & 93.0 & 29.3 & 63.7 \\
\hline \multicolumn{6}{|c|}{ End of cultivation } \\
\hline \multicolumn{6}{|c|}{ Cultivar CC } \\
\hline $\mathrm{S}$ & 120 & 1,960 & 93.9 & 27.1 & 66.8 \\
\hline SGC & 270 & 2,220 & 87.9 & 16.7 & 71.2 \\
\hline SP & 220 & 2,340 & 90.5 & 39.1 & 51.4 \\
\hline $\mathrm{SCF}$ & 110 & 1,710 & 93.3 & 33.0 & 60.4 \\
\hline SCP & 90 & 1,710 & 94.9 & 37.8 & 57.1 \\
\hline SPB & 140 & 1,770 & 92.0 & 33.8 & 58.3 \\
\hline \multicolumn{6}{|c|}{ Cultivar NP } \\
\hline $\mathrm{S}$ & 120 & 2,050 & 94.1 & 12.4 & 81.7 \\
\hline SGC & 250 & 2,300 & 89.3 & 12.8 & 76.6 \\
\hline SP & 220 & 2,290 & 90.2 & 36.8 & 53.4 \\
\hline SCF & 120 & 1,720 & 93.0 & 29.3 & 63.7 \\
\hline SCP & 120 & 1,760 & 93.2 & 15.3 & 77.9 \\
\hline SPB & 120 & 1,760 & 92.9 & 37.5 & 55.4 \\
\hline \multicolumn{6}{|c|}{ Cultivar DB } \\
\hline $\mathrm{S}$ & 100 & 1,930 & 94.9 & 39.9 & 55.0 \\
\hline $\mathrm{SGC}$ & 270 & 2,090 & 87.3 & 16.9 & 70.4 \\
\hline SP & 220 & 2,250 & 90.4 & 47.1 & 43.3 \\
\hline $\mathrm{SCF}$ & 110 & 1,720 & 93.7 & 31.2 & 62.5 \\
\hline SCP & 100 & 1,820 & 94.8 & 33.3 & 61.5 \\
\hline SPB & 120 & 1,680 & 92.6 & 37.5 & 55.2 \\
\hline
\end{tabular}

Table 3. Chemical properties of the six substrates tested in the research before and at the end of cultivation based on the methods of analysis EN13037, EN13038, and EN13652 (de Kreij and Wever, 2005) with minor modifications. ${ }^{\mathrm{z}}$

\begin{tabular}{|c|c|c|c|c|c|c|c|c|}
\hline Substrates & $\mathrm{pH}$ & $\begin{array}{l}\text { Electrical } \\
\text { conductivity } \\
\left(\mathrm{dS} \cdot \mathrm{m}^{-1}\right)\end{array}$ & $\begin{array}{c}\mathrm{N}-\mathrm{NO}_{3} \\
\left(\mathrm{mg} \cdot \mathrm{L}^{-1}\right)\end{array}$ & $\begin{array}{c}\mathrm{N}-\mathrm{NH}_{4} \\
\left(\mathrm{mg} \cdot \mathrm{L}^{-1}\right)\end{array}$ & $\begin{array}{c}\mathrm{P}_{2} \mathrm{O}_{5} \\
\left(\mathrm{mg} \cdot \mathrm{L}^{-1}\right)\end{array}$ & $\begin{array}{c}\mathrm{K}^{+} \\
\left(\mathrm{mg} \cdot \mathrm{L}^{-1}\right)\end{array}$ & $\begin{array}{c}\mathrm{Ca}^{2+} \\
\left(\mathrm{mg} \cdot \mathrm{L}^{-1}\right)\end{array}$ & $\begin{array}{c}\mathrm{Mg}^{+} \\
\left(\mathrm{mg} \cdot \mathrm{L}^{-1}\right)\end{array}$ \\
\hline \multicolumn{9}{|c|}{ Before cultivation } \\
\hline $\mathrm{S}$ & 3.95 & 0.04 & 1.00 & 5.00 & 15.00 & 0.62 & 1.10 & 0.05 \\
\hline SGC & 5.84 & 0.17 & 5.65 & 4.00 & 15.00 & 39.00 & 11.10 & 2.80 \\
\hline SP & 5.09 & 0.02 & 1.00 & 4.00 & 1.50 & 2.40 & 2.30 & 0.06 \\
\hline SCF & 4.12 & 0.04 & 1.00 & 6.00 & 9.00 & 0.95 & 1.50 & 0.09 \\
\hline SCP & 4.30 & 0.05 & 1.00 & 7.00 & 1.00 & 0.47 & 0.64 & 0.13 \\
\hline SPB & 4.15 & 0.04 & 1.00 & 2.50 & 1.00 & 0.35 & 0.21 & 0.13 \\
\hline \multicolumn{9}{|c|}{ End of cultivation } \\
\hline $\mathrm{S}$ & 4.18 & 0.22 & 8.00 & 10.00 & 24.00 & 24.00 & 4.00 & 3.00 \\
\hline SGC & 6.53 & 0.30 & 12.00 & 10.00 & 21.00 & 32.00 & 12.00 & 4.00 \\
\hline SP & 5.70 & 0.32 & 10.00 & 12.00 & 25.00 & 41.00 & 2.00 & 2.00 \\
\hline SCF & 5.07 & 0.15 & 3.00 & 10.00 & 18.00 & 18.00 & 2.00 & 1.00 \\
\hline SCP & 5.37 & 0.17 & 5.00 & 10.00 & 24.00 & 21.00 & 3.00 & 1.20 \\
\hline SPB & 5.05 & 0.20 & 5.00 & 10.00 & 26.00 & 26.00 & 2.00 & 1.00 \\
\hline
\end{tabular}

${ }^{\mathrm{z}}$ Values refer to aqueous extract (substrate/extractant ratio: $1 / 5 \mathrm{v} / \mathrm{v}$ ).

Table 4. Germination index (GI) of cress seed as affected by water extracts of the studied substrates in three concentrations after 48 and $72 \mathrm{~h}$.

\begin{tabular}{cccccccc}
\hline & & \multicolumn{7}{c}{ Substrates } \\
\cline { 3 - 7 } & & $\mathrm{S}$ & $\mathrm{SGC}$ & $\mathrm{SP}$ & $\mathrm{SCF}$ & $\mathrm{SCP}$ & $\mathrm{SPB}$ \\
\hline Incubation 48 h & & & & & & 116 & 71 \\
Water extract & $50 \%$ & 133 & 85 & 89 & - & 132 & 86 \\
& $75 \%$ & 136 & 89 & 101 & - & 140 & 89 \\
& $100 \%$ & 136 & 108 & 95 & - & $129 \mathrm{a}$ & $82 \mathrm{~b}$ \\
Incubation 72 $\mathrm{h}$ & $\mathrm{Mean}^{2}$ & $135 \mathrm{a}$ & $94 \mathrm{~b}$ & $95 \mathrm{~b}$ & - & & \\
Water extract & $50 \%$ & 155 & 78 & 77 & - & 110 & 73 \\
& $75 \%$ & 152 & 86 & 82 & - & 123 & 62 \\
& $100 \%$ & 159 & 94 & 83 & - & 119 & 75 \\
& Mean & $153 \mathrm{a}$ & $86 \mathrm{c}$ & $81 \mathrm{~cd}$ & - & $117 \mathrm{~b}$ & $70 \mathrm{~d}$ \\
\hline
\end{tabular}

${ }^{\mathrm{z}}$ In each row, means followed by the same letter do not differ significantly at $P \leq 0.05$ according to the Student-Newman-Keuls test. represent growth differences important to commercial producers. To better estimate differences in plant growth, form and appearance among the media, several morphological characteristics were measured. Results are reported in Table 5. In general, the alternative growing media tested, except for SCG that showed the lowest values for all the evaluated parameters, performed as well or better than the standard substrate. In particular, SP, SCF, SCP, and SPB had a GI significantly higher than $\mathrm{S}$, showing also a positive effect on tillering capability (shoot number), an important ornamental trait for potted camellias. SPB outperformed S for SPAD values. SGC and SP, characterized by high particle and bulk densities (Table 2), and SCP showed the worst root quality compared with S, SCF, and SPB according to Taylor and Ratliff (1969) and Hernández-Apaolaza et al. (2005). For these two latter parameters, statistical analyses showed an interaction between cultivar and substrate. Analyzing these variables by cultivar (data not shown), 'Dr. Burnside' similarly rooted in all substrates (2.1 to 3.2), whereas 'Charles Cobb's' rooted better in SPB (3.2) and SCP (3.5). In 'Nuccio's Pearl', differences were observed between SGC (2.3) and SCP (3.9). Referring to SPAD, 'Charles Cobb's' did not show differences among substrates (76.10 to 78.15); 'Nuccio's Pearl' performed better in SGC (82.08), SP (82.04), and SPB (81.34) and worst in SCP (71.62). At the opposite, 'Dr. Burnside' showed the highest SPAD values (79.62) in SCP, similarly to SPB (80.66), and the lowest in SGC (73.10).

To better evaluate differences among cultivars, the increase in growth index of each cultivar during the experiment on the six tested growing media was analyzed (Fig. 1). 'Nuccio's Pearl' is typically the most compact shrub, 'Dr. Burnside' the largest, and 'Charles Cobb's' has intermediate characteristics as shown by the growth index values obtained in plants grown in S. Within each cultivar, after 2 months from plantation, no relevant differences were detected among substrates. At the 28th week, reduction in growth was observed in 'Charles Cobb's' at the SGC media and in 'Dr. Burnside' at both the SGC and SPB media. From the 62nd week, in some cases, alternative media outperformed the $\mathrm{S}$, whereas the negative effect of SGC was more evident in all cultivars. In particular, at the end of cultivation, 'Charles Cobb's' plants grew more in SP, SCF, SCP, and SPB; 'Nuccio's Pearl' plants in SP, SCF, and SPB; and 'Dr. Burnside' plants in SCF and SPB. Overall, coconut fibers and pine bark resulted in being the most suitable partial peat substitutes.

\section{Discussion}

Characteristics of growing media. The evaluation of the suitability of peat substitutes for growing containerized ornamental plants was based on physicochemical and biological analyses. In general, the physical properties evaluated were within acceptable ranges (Abad et al., 2001). At the end of 
Table 5. Main effects of cultivar and substrate on growth, chlorophyll content, and flower quality of Camellia japonica.

\begin{tabular}{llcccccc}
\hline & & $\begin{array}{c}\text { Growth index } \\
\left(\mathrm{cm}^{3}\right)\end{array}$ & $\begin{array}{c}\text { Dry } \\
\text { wt }(\mathrm{g})\end{array}$ & $\begin{array}{c}\text { Shoot } \\
\text { number }\end{array}$ & SPAD & $\begin{array}{c}\text { Root } \\
\text { quality }\end{array}$ & $\begin{array}{c}\text { Flower width } \\
(\mathrm{cm})\end{array}$ \\
\hline $\mathrm{cv}$ & $\mathrm{CC}$ & $1,1436.30 \mathrm{a}^{2}$ & $21.51 \mathrm{a}$ & $6.82 \mathrm{a}$ & $77.16 \mathrm{~b}$ & $2.18 \mathrm{c}$ & $9.97 \mathrm{~b}$ \\
& $\mathrm{NP}$ & $8,117.06 \mathrm{~b}$ & $14.87 \mathrm{~b}$ & $6.73 \mathrm{a}$ & $79.42 \mathrm{a}$ & $3.15 \mathrm{a}$ & $10.84 \mathrm{a}$ \\
& $\mathrm{DB}$ & $11,193.49 \mathrm{a}$ & $17.18 \mathrm{~b}$ & $5.70 \mathrm{~b}$ & $77.08 \mathrm{~b}$ & $2.60 \mathrm{~b}$ & $11.14 \mathrm{a}$ \\
Substrate & $P$ & $<0.001$ & $<0.001$ & $<0.001$ & $<0.05$ & $<0.001$ & $<0.001$ \\
& S & $8,714.48 \mathrm{~b}$ & $16.17 \mathrm{a}$ & $5.47 \mathrm{~b}$ & $76.87 \mathrm{~b}$ & $2.73 \mathrm{bc}$ & 11.00 \\
& SGC & $6,160.91 \mathrm{c}$ & $10.74 \mathrm{~b}$ & $5.51 \mathrm{~b}$ & $77.78 \mathrm{ab}$ & $2.00 \mathrm{~d}$ & 10.37 \\
& SP & $11,560.13 \mathrm{a}$ & $19.30 \mathrm{a}$ & $7.55 \mathrm{a}$ & $78.37 \mathrm{ab}$ & $2.40 \mathrm{~cd}$ & 10.31 \\
& $\mathrm{SCF}$ & $12,048.55 \mathrm{a}$ & $22.14 \mathrm{a}$ & $6.48 \mathrm{ab}$ & $77.08 \mathrm{~b}$ & $3.37 \mathrm{a}$ & 10.61 \\
& $\mathrm{SCP}$ & $10,786.27 \mathrm{a}$ & $17.59 \mathrm{a}$ & $6.57 \mathrm{ab}$ & $77.00 \mathrm{~b}$ & $2.30 \mathrm{~cd}$ & 10.10 \\
& $\mathrm{SPB}$ & $12,566.17 \mathrm{a}$ & $21.18 \mathrm{a}$ & $6.77 \mathrm{ab}$ & $79.78 \mathrm{a}$ & $3.07 \mathrm{ab}$ & 10.44 \\
& $P$ & $<0.001$ & $<0.001$ & $<0.001$ & $<0.05$ & $<0.001$ & $\mathrm{NS}$ \\
$\mathrm{cv} \times$ substrate & $P$ & NS & NS & NS & $<0.001$ & $<0.05$ & NS \\
\hline
\end{tabular}

${ }^{\mathrm{z}}$ In each column, means followed by the same letter do not differ significantly according to the StudentNewman-Keuls test.

NS $=$ nonsignificant.
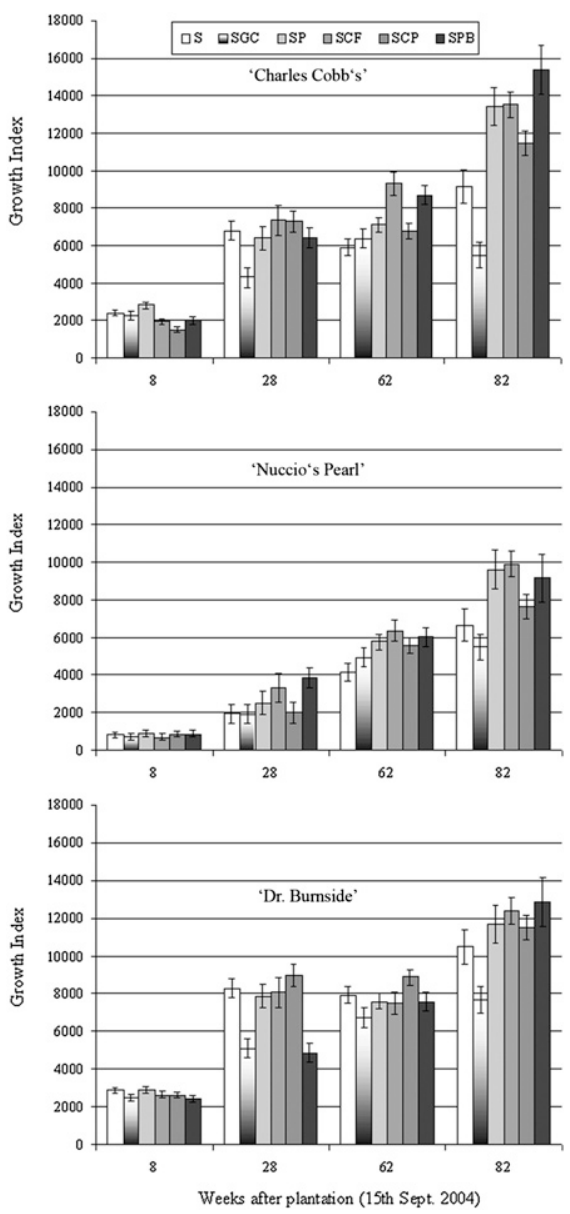

Fig. 1. Changes in growth index of the three Camellia japonica cultivars during cultivation on the six tested growing media $(\mathrm{S}=$ standard; $\mathrm{SGC}=\mathrm{S}+$ green compost; $\mathrm{SP}=\mathrm{S}+$ pumice; $\mathrm{SCF}=\mathrm{S}+$ coconut fibers; $\mathrm{SCP}=\mathrm{S}+$ coconut peat; $\mathrm{SPB}=\mathrm{S}+$ pine bark). Mean and standard deviation of 12 replicates are shown.

cultivation, the substrates showed in all the cultivars similar characteristics apart from the AS and WC. This could be the result of cultivar differences in roots and evapotranspiration. More in detail, in the substrates containing green compost and pumice, the particle density was greater than the established limit for an ideal substrate (Abad et al.,
2001). Similar results were obtained for porosity, which determines the rate at which air can move through the substrate. The low porosity of media containing compost was already established by several authors (Hernández-Apaolaza et al., 2005). As expected, the partial substitution of peat with alternative materials decreased the WC, except for coconut peat.

At the end of the trial, EC increased for all the substrates, but remained always within the recommended range. As far as $\mathrm{pH}$, all substrates presented values lower than the acceptable range but similar to the standard substrate used for acidophilus species such as camellia, the indicator crop. Previous studies with compost demonstrated that salinity can be a limiting factor to its use as a substrate component (Castillo et al., 2004; SánchezMonedero et al., 2004). Also in this experiment, compost addition increased both $\mathrm{pH}$ and $\mathrm{EC}$ values and nutrient availability of the substrate with a negative effect on the growth of camellias tested (Table 5).

Concerning the phytotoxicity, all substrates evaluated showed GI higher than $50 \%$, which means they are acceptable for being used for potted plant production (Urrestarazu et al., 2001).

Camellia plant development. Plants in all the media appeared healthy throughout the cultivation period and did not show symptoms of nutrient deficiency or toxicity at any time.

Results concerning plant growth and ornamental value of camellias (Table 5) varied significantly among both substrates and cultivars, pointing out the influence of the genotype on cultivation response, especially for SPAD and root quality.

As shown in Figure 1, for each cultivar, the effect of the substrates on plant growth was different in relation to the cultivation phase. About 40 weeks after plantation, pruning and transplanting affected the plant growth. After these operations, especially 'Nuccio's Pearl' and 'Dr. Burnside' plants, showed differences related to their attitude to start their vegetative growth again. The negative effect of SGC on plant growth was probably related to the increased $\mathrm{pH}$ (Table 3 ). This could be possibly countered by more composting and by adapting fertilizer doses to the medium. In fact, the use of partial peat substitutes in horticultural crop production needs to determine fertilizer requirements in these new substrates compared with the traditional medium. In addition, specific irrigation programs have to be defined to maximize plant performances and minimize nutrient waste and loss in the environment.

\section{Conclusions}

It can be concluded that peat can be partially substituted by coconut fibers, coconut peat, pine bark, or pumice, whereas the use of green compost can negatively affect plant growth. The choice of which peat substitute to use depends on their costs and availability. Considering both technical and economical factors, coconut fibers can be a good alternative for camellia potted plant production. Fertilizer and irrigation recommendation for growing camellias in this substrate will help growers increase plant growth and quality and minimize fertilizer and water use, reducing both costs and losses to the nursery.

\section{Literature Cited}

Abad, M., P. Noguera, and S. Bures. 2001. National inventory of organic wastes for use as growing media for ornamental potted plant production: Case study in Spain. Bioresour. Technol. 77:197-200.

Arshad, M.A. and S. Martin. 2002. Identifying critical limits for soil quality indicators in agro-ecosystems. Agric. Ecosyst. Environ. 88:153-160.

Barreto, M.S. and K.B. Jagtap. 2006. Assessment of substrates for economical production of gerbera (Gerbera jamesonii Bolus ex Hooker F.) flowers under protected cultivation. J. Ornamental Hort. 9:136-138.

Beltrami, M., D. Rossi, and R. Baudo. 1999. Phytotoxicity assessment of Lake Orta sediments. Aquat. Ecosyst. Health Manage. 2:391-401.

Castillo, J.E., F. Herrera, R.J. López-Bellido, F.J. López-Bellido, L. López-Bellido, and E.J. Fernández. 2004. Municipal solid waste (MSW) composts as a tomato transplant medium. Compost Sci. Util. 12:86-92.

de Kreij, C. and G. Wever. 2005. Proficiency testing of growing media, soil improvers, soils, and nutrient solutions. Commun. Soil Sci. Plant Anal. 36:81-88.

Erhart, E., W. Hartl, and B. Putz. 2005. Biowaste compost affects yield, nitrogen supply during the vegetation period and crop quality of agricultural crops. Eur. J. Agron. 23:305-314.

Fascella, G., G.V. Zizzo, C.V. Costantino, and S. Agnello. 2003. Effect of different substrates on soilless cultivation of Ruscus hypoglossum for cut foliage production. Acta Hort. 614:211-215.

Garcia-Gomez, A., M.P. Bernal, and A. Roig. 2002. Growth of ornamental plants in two composts prepared from agroindustrial wastes. Bioresour. Technol. 83:81-87.

Grigatti, M., M.E. Giorgioni, L. Cavani, and C. Ciavatta. 2007. Vector analysis in the study of the nutritional status of Philodendron cultivated in compost-based media. Sci. Hort. 112:448455 . 
Guérin, V., F. Lemaire, O. Marfà, R. Caceres, and F. Giuffrida. 2001. Growth of Viburnum tinus in peat-based and peat-substitute growing media. Sci. Hort. 89:129-142.

Guerrero, F., J.M. Gascó, and L. Hernández-Apaolaza. 2002. Use of pine bark and sewage sludge compost as components of substrates for Pinus pinea and Cupressus arizonica production. J. Plant Nutr. 25:129-141.

Gutiérrez-Miceli, F., J. Santiago-Borraz, J.A. Montes Molina, C.C. Nafate, M. Abud-Archila, M.A. Oliva Llaven, R. Rincón-Rosales, and L. Dendooven. 2007. Vermicompost as a soil supplement to improve growth, yield and fruit quality of tomato (Lycopersicum esculentum). Bioresour. Technol. 98:2781-2786.

Hargreaves, J.C., M.S. Adl, and P.R. Warman. 2008. A review of the use of composted municipal solid waste in agriculture. Agr. Ecosyst. Environ. 123:1-14.

Hernández-Apaolaza, L., A.M. Gascó, J.M. Gascó, and F. Guerrero. 2005. Reuse of waste materials as growing media for ornamental plants. Bioresour. Technol. 96:125-131.

Hidalgo, P.R. and R.L. Harkess. 2002. Earthworm castings as a substrate for Poinsettia production. HortScience 37:304-308.

Hoekstra, H.J., T. Bosker, and E.A. Lantinga. 2002. Effects of cattle dung from farms with different feeling strategies on germination and initial root growth of cress (Lepidium sativum L.). Agr. Ecosyst. Environ. 93:189-196.

Jackson, L.E., U. Pascual, and T. Hodgkin. 2007. Utilizing and conserving agrobiodiversity in agricultural landscapes. Agr. Ecosyst. Environ. 121:196-210.

Klock, K.A. 1997. Growth of salt sensitive bedding plants in media amended with composted urban waste. Compost Sci. Util. 5:55-59.
Lennartsson, M. 1997. The peat conservation issue and the need for alternatives. In: Proc. of the IPS International Peat Conference on Peat in Horticulture. Schmilewski, Amsterdam. p. 112-121.

Marfà, O., F. Lemaire, R. Caceres, F. Giuffrida, and V. Guerin. 2002. Relationships between growing media fertility, percolate composition and fertigation strategy in peat-substitute substrates used for growing ornamental shrubs. Sci. Hort. 94:309-321.

Meerow, A.W. 1994. Growth of two subtropical ornamentals using coir (coconut mesocarp pith) as a peat substitute. HortScience 29:1484 1486.

Meerow, A.W. 1995. Growth of two tropical foliage plants using coir dust as a container media amendment. HortTechnology 5:237239.

Moldes, A., Y. Cendon, and M.T. Barral. 2007. Evaluation of municipal solid waste compost as a plant growing media component, by applying mixture design. Bioresour. Technol. 98:30693075.

Offord, C.A., S. Muir, and J.L. Tyler. 1998. Growth of selected Australian plants in soiless media using coir as substitute for peat. Aust. J. Exp. Agr. 38:879-887.

Pinamonti, F., G. Stringari, and G. Zorzi. 1997. Use of compost in soilless cultivation. Compost Sci. Util. 5:38-46.

Prasad, M. and M.J. Maher. 2001. The use of composted green waste (CGW) as a growing medium component. Acta Hort. 549:107113.

Ribeiro, H., A.M. Romero, H. Pereira, P. Borges, F. Cabral, and E. Vasconcelos. 2007. Evaluation of a compost obtained from forestry wastes and solid phase of pig slurry as a substrate for seedlings production. Bioresour. Technol. 98:3294-3297.

Sánchez-Monedero, M.A., A. Roig, J. Cegarra, M.P. Bernal, P. Noguera, M. Abad, and A. Antón. 2004. Compost as media constituents for vegetable transplant production. Compost Sci. Util. 12:161-168.

Scagel, C.F. 2003. Growth and nutrient use of ericaceous plants grown in media amended with sphagnum moss peat or coir dust. HortScience 38:46-54.

Smith, B.R., P.R. Fisher, and W.R. Argo. 2004 Growth and pigment content of containergrown Impatiens and Petunia in relation to root substrate $\mathrm{pH}$ and applied micronutrient concentration. HortScience 39:1421-1425.

Stamps, R.H. and M.R. Evans. 1997. Growth of Dieffenbachia maculata 'Camille' in growing media containing Sphagnum peat or coconut coir dust. HortScience 32:844-847.

Taylor, H.M. and L.F. Ratliff. 1969. Root elongation rates of cotton and peanuts as a function of soil strength and soil water content. Soil Sci. 108:113-119.

Urrestarazu, M., M.C. Salas, M.I. Padilla, J. Moreno, M.A. Elorrieta, and G.A. Carrasco. 2001. Evaluation of different composts from horticultural crop residues and their uses in greenhouse soilless cropping. Acta Hort. 549:147-152.

van der Gaag, D.J., F.R. van Noort, L.H.M. StapelCuijpers, C. de Kreij, A.J. Termorshuizen, E. van Rijn, S. Zmora-Nahum, and Y. Chen. 2007. The use of green waste compost in peat-based potting mixtures: Fertilization and suppressiveness against soilborne diseases. Sci. Hort. 114:289-297.

Zucconi, F., A. Pera, M. Forte, and M. De Bertoldi. 1981. Evaluating toxicity of immature compost. Biocycle 22:54-57. 